\title{
THE FORMULATION OF LOCAL VALUES-BASED RECOVERY PROGRAM (LEARNING FROM THE EXPERIENCE OF THE PROVINCIAL GOVERNMENT OF EAST NUSA TENGGARA-INDONESIA)
}

\begin{abstract}
The research aims to determine how the social design of policy formulation in recovery after disasters and social conflicts. The method used in the study is a qualitative research design, data collection techniques through documentation and interviews with key informants. The recovery of the public life after reconstruction due to natural disasters and social conflicts demanding greater government attention to solve bersoalan arising through the formulation of programs oriented to local values. The importance of such a policy given that the public is the target to be met interests, and basically in their social life with values that serve as a guide in achieving a common goal. The Formulations recovery program based value is essentially a process of public policy formulation design also is social design process that relies on the dimension; (1) a value appreciation of relevant actors; (2) an orientation toward conflict resolution, problem solving, and change. The first dimention concerns an administrator's to listen to other voices, share in others experiences, and gain new knowledge. The second describes the administrator's orientation toward conflict resolution, problem solving, and change; the administrator's actions can range from proactive to reactive. Research indicates that, the experience of local government in the province of East Nusa Tenggara post-disaster and conflict should be a lesson for having successfully implemented local values-based formulation design in formulating regional development programs.
\end{abstract}

Key word: local values, policy formulation, social design

\section{Introduction}

The Province of Nusa Tenggara Timur-Indonesia, province in Indonesia is vulnerable to natural disasters and social conflicts. The catastrophic natural disaster ever to hit this province is the tsunami disaster in 1992 that killed 1952 people and injured 2126, whereas social conflict in general is the issue of

Nursalam, Dr.M. Si, Faculty of Social and Political Sciences, University of Nusa Cendana, Kupang, Indonesia, e-mail: nursalamjeppu@yahoo.com 
land, namely disputes regarding boundaries of neighboring communities, and communal land ownership issues.

The implications generated by disasters and social conflicts are people suffering and trauma. The question then becomes the main concern of local governments to find a way out to feel peaceful and well-being to be recovered.

Efforts taken by local governments to recover after disaster strikes the community and social conflicts are addressed through a range public policies oriented development programs of local values. Local values are the values that flourish in a society that has been used as interact to achieve the purpose of the society.

Importance Of these local values in the formulation of policies to improve social conditions after the disaster and social conflicts become urgent because the top-down policies that are sometimes ignored the interests and needs of the affected communities and social conflict. Mapping to the needs and interests of local communities are less accommodated because the policies are made not consider the perspective of the target group. According to Edward III (1980:13), that if public policy is viewed from the perspective of policy customers, then value judgments are inevitable. This view confirmed that policies that work should pay attention to the condition of the people, because they will be affected by a policy. Just as also noted by Saifullah (2008:39), which states:

"The problem that arises due to a mismatch between the policy taken by the state in the field, sometimes the problem is regarding the aspects that cannot be measured quantitatively. For example, in relation to the system of values, cultural differences, understanding or perception, sense of justice, and freedom, and so forth"

The views of both writers are reinforced by the opinions Nurjaya (1985), which states that the policy that ignores local values ultimately led to the marginalization of local communities. Model Policies into top-down and not rooted in local cultural values.

In the last three decades product public policy are taken by the government in dealing with natural disasters and social conflicts tend to showed characteristics of patterned centralized, exploitative, sectoral, closing the space for transparency and public participation, ignoring the rights of local communities. The ways that resulted in: (1) neglect of the principles of justice; democracy, public participation; (2) create marginalization and destruction of the social order, local culture as a centralized government is required to be standardized; (3) occurred the criminalization process, victimization, and dehumanisasi of local community activity in the utilization of development, stigma tends degrade existence of local communities, (Nurjaya, 1985).

Therefore the need for reform in post-disaster management policy and social conflict by considering local values. The reason for the local community as a layer of grass roots support system with the knowledge that they have quite 
thick and flexible in the face of various challenges, they remain survival through a process of continuous adaptation over the centuries with the environment in which they live. This article aims to determine the extent of social design formulation of policies adopted in recovery after disasters and social conflict case study of East Nusa Tenggara province of Indonesia.

\section{Theoretical framework}

\subsection{The value and Decision Making}

Any decision regarding public interest should consider the values prevailing in society. The attention to the dimensions of this value also because of the condition of the administration- politic dichotomy (Waldo, 1949:169), which explains that, values and political power has been in operation starting from the stage of agenda setting up the policy process to street-level policy implemementasi.

The assumptions built into the decision-making is also based on the notion that politics is generally defined as allocating values authoritatively or determination process, who gets what, where, and how? Of course this is in line with the diffusion theory (Frederickson, 1997, p. 41), which states the importance of the fit between the goals and the change of the dominant values in society. Values such as empathy., honesty, ability to innovate, and the value of concern for the public interest so to help policy-makers perform the duties entrusted to him.

The values are used as the basis for policy-making is also influenced by other factors in the decision-making process, as proposed by Winarno (2002, p. 93), which states that:

"The problem then is the criterion (of values or measures) such as whether that influence political decision-makers? To answer these questions we will be faced with many factors that influence the decision makers, such as political pressures and social, economic conditions, procedural requirements, prior commitments, etc".

According to Anderson (2003, pp. 126 - 127), that there is various values that surround and guide the policy makers in the decision-making process, namely organizational values, professional values, personal values, the values of the policy, and ideological values . Overall these values are widely considered by the decision maker. There is a tendency of public decision-makers to ignore the values held in the decision making process, when actually they are very helpful in determining what is good, bad, desirable or undesirable. The relationship between decision making and attention to the values of the public or the public interest represented by Michael (2003, p. 21), in his book entitled "The Foundation of Public Policy", that there are 5 main elements of any decision that is supposed to represent the public interest / public values namely: (1) recognition 
of the rights of the individual; (2) attention to the public; (3) accountability of decision makers to the public; (4) representation public; (5) a formal process to separate and restrict the role of the decision maker.

Rational decision makers to always be rational, namely the manner in which effective policies that can be implemented. Rationality based on means-ends logic, which assumes that the best option was approved by the policy objectives. In the decision-making process, alternatives have been considered a great way for the achievement of goals. Therefore in decision theory, rationality is to minimize risk and ensure institutional continuity as a goal or value (Simon, 1947, p. 164). Rationality in decision-making processes be concerned to the selection of alternatives, actually intended not merely to maximize their values, but simply reached a level of satisfactory or good enough (Wahab, 1990, p. 65). Satisfaction is described and rational attitude allows administrators which face certain decisions, simplifies the problem by not examining all possible alternatives. In this case the administrator seems to follow common sense, making important choices that may be overlooked. Hence the concept of rational according to Simon (1947, p. 165) called bounded rationality.

The policy analyst careful that bias make recommendations on the goals and values, because these recommendations help the analyst to provide input to a conclusion about the main alternatives in decision-making can actually be applied to problem Solving the problem faced by the public. Associated with this, Dror in Wahab (1990, p. 66), presented a number of suggestions that rational decisions can be made, namely: (a) knowing the values of the whole society; (b) knowing precisely the policy alternatives available; (c) knowing all the possible consequences of each alternative selected policy; (d) calculate the ratio between the value achieved by the community with the sacrifice that has been given by them for each policy alternative selected; (e) choosing the most efficient alternative.

To carry out suggestions as proposed above, according to Wahab (1990, p. 66), public policy makers should take the following steps: (a) formulate and create hierarchy that it controls values; (b) formulate specific goals that match those values; (c) identify all relevant options or the means to achieve these goals; (d) calculate all the result of earlier choices and compare them with each other; (e) set options or combine the best choices are seen to maximize the achievement of the values that have been defined previously.

\subsection{The Role of Values in Public Policy}

Some studies show that the success of a policy is determined by the extent to which the policy attention to the values embraced, either by formulators, implementing policies and values held by the target policy, where the policy is applied. The results of study done by Nursalam (2009) showed that the implementation 
of the policy because the results are not optimal since the policy formulation to implementation factors ignored public values.

The value in the organization is essentially something that is considered important to be used as a guide in achieving a common goal. According to Schein $(1985$, p. 7$)$ value is expressed as:

"The basic assumption, which is discovered or developed by a group of people as they learn to cope with problems of external adaptation and internal integration, that has worked well so it is considered valid to be taught to members of the code of conduct".

From that perspective, the value of the system can be expressed as a composition of the principles and rules to help someone choose alternatives, resolve conflicts, and make decisions, materialized into a cultural value. As such a value includes an interconnected pattern or structured values that appear on each level, both at the individual, group, organization or society, the values are placed in a hierarchical arrangement is significant. A normal value is relatively stable or slow change, and have the ability to influence behavior and decision making specific choices or decisions. The value judgment occurs when a value applied to the policy-making situation, or on some aspect of the policy process.

Tachjan (2006, p. 119), further argued that:

„The norms of behavior and attitude patterns are a set of values of shared meaning of the members of the organization in the belief, assumptions, perceptions, preferences, outlook and attitude in overcoming the problem. Shared meaning, shared understanding, or collective mind, is a sense of togetherness in the organization's members have and use those values as a characteristic, prevailing the long time, different from other organization, and can be taught from one generation to the next".

These values are creating artifacts in the form of technology, art, patterns of behavior. These values arise due to the presence of the basic assumptions relating to the mutual relationship with the environment, the nature of the reality of time and place; nature of human nature; nature of human activity, and the nature of human relationships. The shared values will become members of the organization in carrying handle and is the foundation obligation to behave, as well as a guide for dealing with problems of external adaptation and integration efforts into the organization so they know how they should act. Thereby the values of the organization can be used to achieve a competitive advantage and organizational effectiveness through the formation of attitudes and behavior patterns of members of the organization work.

Based on the views of some of the functions of the values or culture as presented above, the in the development of public policy formulation theory of Jones (1994, p. 164) take relevant dimension of value as an important determinant. 
As also stated by Dunn (1981, p. 87), that value is "The Systematic, reasoned, and critical examination of values is an essential element of policy analysis". The condition empirical policy formulation showed that the failure of government programs related efforts with the values embraced by the formulators and implementers apparatus as well as the target of the policy. Several main values such as accountability, transparency, efficiency, effectiveness, responsibility, and competition, as well as the values of social justice is less in the formulation and implementation of government policy.

Such as the value of social justice according to Frederickson $(1984$, p. 43), emphasizing on: (1) equality in government service; (2) accountability for decision-making and implementation of programs of public managers; (3) changes in public management; (4) responsiveness to citizens' needs rather than the needs of public organizations; (5) an approach to the study of the administration that is interdisciplinary, applied and solve problems as well as theoretically healthful.

The issue of the importance of the dimension values or environmental factors in the formulation of public policy has been included by some authors as a-dimensional, as proposed by Simeon (1976, p. 550), which states:

"Machine politics and policy-makers are and work within a framework that severely limit their alternatives and innovations. The framework is shaped by socio-economic, power systems, the ideas, the values dominant in society, as well as the institutional structure of society. The policy process cannot be separated from the ideas, namely culture and ideology. A policy is a function of the ideas, values, theories, and beliefs dominant in society".

Meanwhile Smith (1973, p. 200) in his book entitled "The policy implementation process", suggests environmental factors as one of the dimensions to see the implementation of public policy. Smith (1973, p. 200), argues four variables in policy implementation, namely: the idealized policy, the implementing organization, the target group, and environmental factors. Environmental factors are factors that may affect or be affected by the implementation of the policy, may be a condition of cultural, social, political, and economic. The understanding of influence of environmental factors is very important because public policy may not be separated from the influence of the environment in which policy is made and implemented, including the environmental factor is the political culture, public opinion, social systems, and economic systems. According to Nakamura and Smallwood (1980, p. 22), environmental of policy implementation are occupied by different people, depending on the policy that is being implemented. They are policy makers, policy implementers official, middleman, voter groups, community groups affected by the policy, the media and the policy evaluator.

Various problems faced by the community is not enough to just set a formal policy through so many failures in policy implementation, as it by Kartodiharjo 
(2006, p. 31), to minimize the limitations, policies need to be put in at least five aspects, namely:

1) Values are shared;

2) Academic or empirical evidence already known the truth;

3) Getting political support, that gets a deal or win the votes obtained by the limits set representation;

4) Implemented by the organization or institution is capable perform it;

5) Be accepted by society at large, especially the direct contact with the running of these policies.

\section{Methods}

The research uses a qualitative research design with a descriptive analysis method. According to Creswell (1994, p. 173) argues that qualitative research is interpretative research. As such, the biases, values and judgement of the researches become stated explicitly in the research report. Such openess is considering to be useful and positive. The use of this method is to describe and assess qualitatively, extent of the formulation of local value-based recovery programs after disasters and social conflict in the province of Nusa Tenggara Timur.

Determination of the informants in this study are determined by purposive, with the snowball technique. At first the researchers met informants base, namely: members of the House of Representatives of the Republic of Indonesia, officials in the Regional Development Planning Agency, academic observers of social development who knows the other as informants or key informants. Key informants in this study obtained or known based on a recommendation from the base of the first informants researchers encountered.

\section{Results and discussion}

\subsection{Overview Nusa Tenggara Timur Province}

Nusa Tenggara Timur Province (NTT) consists of 20 regency and 1 city with a population of 4,679,316 inhabitants. NTT consist of 1,192 islands but only 42 inhabited islands, which lie between $8^{\circ}-12^{\circ}$ South latitude and $118^{\circ}-125^{\circ}$ East Longitude, with a total land area of $48,718.1 \mathrm{~km} 2$. In climatology, NTT is a semiarid areas with low rainfall. Wet or rainy season is usually quite short about 3 to 4 months with average lowest annual rainfall of $800 \mathrm{~mm}$ and $3,000 \mathrm{~mm}$ high.

NTT province's economy depends on agriculture which contribute $39.62 \%$ of the Gross Domestic Product (GDP). NTT economic growth rate was 5.63\% in 
2011 while the growth in the national economy in the same year reached $6.46 \%$ (Gismar dkk, 2013).

NTT Human Development Index increased gradually in recent years. Yet low income levels and high prevalence of malnutrition in NTT puts ranked 31 out of 33 provinces in 2009 (Map of Food Security and Vulnerability NTT, 2010). NTT provincial government determined to bring prosperity to the community by Setting 8 (eight) agenda development strategy, namely: (1) strengthening the quality of education; (2) health Development; (3) economic development; (4) infrastructure development; (5) systems development of a righteous law; (6) consolidation of spatial and environmental stewardship; (7) empowerment of women, children, and young; (8) special agenda including poverty reduction, development of border areas, the development of the islands, and development of a natural disaster-prone areas.

NTT provincial government with the support of all local government in NTT province strive to develop their leading centers to make this area as a provincial livestock, corn provinces, sandalwood province, and the provincial cooperative. With largely topography of the area is hilly and mountainous, land slope reaches $>40 \%$ most of the production area is located on land with a slope of $8-40^{\circ}$, consequently very high erosion potential and cause degradation rate of land resources is high, even vulnerable to natural disasters.

In the following table 1 shows the number of disasters in the province of NTT over the period 1992-2008.

Table 1: The Type Natural Disaster in Nusa Tenggara Timur Province (Village Potential Statistics of Province Nusa Tenggara Timur, 2008)

\begin{tabular}{|l|l|c|}
\hline No & The Types of Natural Disaster & Frequency \\
\hline 1 & Landslide & 51 \\
\hline 2 & Flood & 177 \\
\hline 3 & Flood with Materials & 29 \\
\hline 4 & Earthquake & 6 \\
\hline 5 & Earthquake with Tsunami & 1 \\
\hline 6 & Tide & 153 \\
\hline 7 & Tornado & 223 \\
\hline 8 & Volcanic Eruption & 5 \\
\hline 9 & Forest on Fire & 53 \\
\hline & Total & $\mathbf{6 9 8}$ \\
\hline
\end{tabular}

The incidence of the biggest disasters that ever happened NTT province, which is earthquakes with tsunami in 1992, when the amount 152 dead, 2126 injured people (NTT Natural Disaster Management Agency, 2008). 


\subsection{Social Conflict in Nusa Tenggara Timur Province}

The conflicts that have occurred since 2005-2010 in communities in the province of Nusa Tenggara Timur has caused many losses including the number of people who died 14 people, 259 injuries, losses estimated 681 billion Rupiah. In general, a conflict dominated by conflict over land, which is caused by: (1) the issue of ownership of Indigenous / indigenous, either individually or in groups, (2) Land

The latest incident happened is 20 attack on the home of inhabitant in the village of Langga Lete,Wewewa Barat, Sumba Barat Daya - NTT. The incident was triggered by a land dispute between the perpetrator and the victim that resulted in disaster. Chronological events namely: on 6 March 2013, 20 people attacked the victim who has just wrapped up happily on his new home. A threeyear-old son was also hit by a stone in the head. The child was treated at Caritas Hospital, Waitabula (capital Sumba Barat Daya), but his soul is not saved. He died on March 10, 2013.

Land disputes in various areas in NTT, there has been a long time. Previously, also in June 2011, in the village of Reda, Southwest Sumba, five people were killed over a land dispute. (Peace and Policy Studies, 2013). As a whole in NTT from 2005 to 2010 the amount land disputes as many as 255 cases, of the amount of new 189 was already resolved 66 cases while in handling. (Report on the work visit Council of Representatives, 2010)

\subsection{Design of Policy Formulation Based Local Value}

Jun (2006) argues that accommodate local values are very vital in the formation of public policy, to reach the value of one of the models offered are social model. Design or social model is the interaction of two main dimensions, namely: (1) a value appreciation of relevant actors; (2) an orientation toward conflict resolution, problem solving, and change. The first dimention concerns an administrator's to listen to other voices, share in others experiences, and gain new knowledge. The second describes the administrator's orientation toward conflict resolution, problem solving, and change; the administrator's actions can range from proactive to reactive.

Furthermore according to the Jun (2006) social design is a synthesis between the rational and incremental design frame (science and art) offers a conceptual lens that leavens interactive processes with political and social skills. The public administration should be seen as science but more than science, more than artconstructive syntesis-with skillful administrators drawing from either or both perspectives to understand the complex dimentions and move their facilitative and deliberative process forward, anticipating contestation among the stakeholders and any actor who might be affected by the outcome of a decision. 
The social design as a conceptual metaphor for this field because it goes beyond the range of the other approaches to include philosophical and social considerations that better represent the real world of public administration. Therefore, the social model is combines a high appreciation of the values of relevant actors by focusing on interpretation, understanding, sharing, and learning in organizational and social relationship and by taking a proactive stance regarding conflict resolution, learning, problem solving, and change. The essence of social design is develop of prosess that facilitates interaction and participation stakeholders in policy formulation.

In the process of policy formulation is created as viable alternatives are formulated through sosial interaction and networking among administrators, experts, politician, social groups, clients, and citizens associated with specific issues and problems. The process of social design assues that design participants work to create solution that are relevant to the problem and the means for implementing these solution.

Purposes and goals are socially constructed, developing out of human interaction, dialogue, and mutual learning. Political consensus is not then ultimate goal of social design. The focus, instead, is on understanding different ideas, experiences, and technical and social knowledge and on developing shared responsibility through decentralization.

Through this social model of the social conflicts can be overcome and find a way out. According to Schattschneider (1960) public policy can be seen as a conflict between various groups in society are different views and interests.

\subsection{The formulation of Public Policy-oriented local value}

The formulation of public policy is the beginning of a series of policy process, with the understanding that the actual formulation of policy will provide direction in order to implement the policy effectively. Results will direct policy formulation and impact to the people, that is the impact of not only the behavior of administrastif agencies responsible for implementation of and compliance with the target group, but also a network of direct and indirect political power, economic, social involved in the implementation of the program.

The formulation of programs or policies, may not be implemented in empty space, therefore environmental factors will affect the program formulation process. According to Lindblom (1968), in understanding the process of policy formulation we need to understand the actors involved in the policy formation process, both the actor and the actor is not officially authorized. The actors have a role, a form of power, have interaction with each other, and they watch each other.

This paper focuses on how policy formulation associated with local values . As noted by Anderson (1969) that in the formulation and formation of policies 
to consider local values, due to the formation of policy is basically the result of a dynamic social process.

Policy formulation is a dynamic social process of implementation and continuous improvement of the policy as a result of changes in resources and environment. Winarno (2011), argued that in order for an organization remain alive, then changes may be made so that the organization can adapt to its environment. Changes taking place, both related to organizational resources and the environment should respond through changes to organizational policies. As such, the processes that occur within the organization regarding policy formation as adaptation to changes in society.

Based on the data obtained that the programs drawn up by the government based on local values indicated in the table 2 .

One example of the program as shown in the table 2 is the Community Food Institutional Development Program, designed to; (1) institutional strengthening food security in support of rural household food security; (2) increasing the role of the community in the improvement of household food security. The main activities of this program are: (1) develop a model of independent food institutions in rural; (2) optimizing the role of social institutions in the rural culture of food security; (3) coordination of food security across sectors, regions, and actors.

Table 2: Programs Based on Local Values (Nusa Tenggara Timur Province Local Regulation No. 2 of 2004)

\begin{tabular}{|l|l|l|}
\hline Item & Programs & Sector \\
\hline 1 & The Program of Improvement Production and Productivity of Farmers. & Ekonomi \\
\hline 2 & The Program of Institutional development of Community Food. & Economy \\
\hline 3 & The Program of Cooperative Partnership Model Development & Economy \\
\hline 4 & $\begin{array}{l}\text { The Program of Improvement and Maintenance of Roads and Bridges } \\
\text { Infrastructure }\end{array}$ & Economy \\
\hline 5 & The Program of Settlement Facilities and Infrastructure Development & Economy \\
\hline 6 & The Program of Development of Basic Education & Human Resources \\
\hline 7 & The Program of Health Service Quality & Human Resources \\
\hline 8 & $\begin{array}{l}\text { The Program of Family Planning, Reproductive Health and Family } \\
\text { Empowerment }\end{array}$ & social welfare \\
\hline 9 & The Program of Strengthening Inter-Religious Harmony Life & religion \\
\hline 10 & The Program of Rehabilitation of Critical Land & $\begin{array}{l}\text { Spatial and the } \\
\text { Environment }\end{array}$ \\
\hline
\end{tabular}

As a follow-up program has been drawn up, the government allocates funds for the implementation of the program to, as shown in the table 3 
Table 3: Financing Development in Nusa Tenggara Timur Province during 2006-2010 (Report of the Working Visit House of Representatives, 2010)

\begin{tabular}{|c|c|c|c|c|}
\hline Year & $\begin{array}{c}\text { The Local Revenue } \\
(\mathbf{R p})\end{array}$ & $\begin{array}{c}\text { Central Government } \\
\text { Transfers (Rp) }\end{array}$ & $\begin{array}{c}\text { The local Revenue } \\
(\%)\end{array}$ & $\begin{array}{c}\text { Central Government } \\
\text { Transfers (\%) }\end{array}$ \\
\hline 2006 & 151.158 .639 .000 & 513.639 .600 .000 & 22,74 & 77,26 \\
\hline 2007 & 191.852 .909 .366 & 657.845 .006 .000 & 22,58 & 77,26 \\
\hline 2008 & 208.190 .685 .000 & 730.741 .315 .000 & 22,17 & 77,83 \\
\hline 2009 & 223.882 .850 .000 & 1.536 .272 .665 .334 & 12,72 & 87,28 \\
\hline 2010 & 286.095 .616 .683 & 789.653 .559 .386 & 26,60 & 73,40 \\
\hline
\end{tabular}

The data in the table 3 showed that the ability of local governments to allocate funds for the development is still very limited, which is only capable of $26,60 \%$ of all outstanding loans. Central Government dominates the whole process of development financing.

\section{Conclusions}

The Local value as a public value for a particular locality are become very urgent for the guidance of government administration and development, government task is to accommodate local values in carrying out its duties and functions. This obligation is actually a form of government responsibility in the welfare of its people. In extreme Moore (1994) argues that the government should carry out the task of accommodating the local value through the creation of public value by arguing that managers should create public value encourages a kind of leadership, entrepreneurialism, and opportunism that should be reserved for those who run for office, not those who run public organisations. It gives public managers too much encouragement to lose the constraints of principle and effective democratic oversight and pursue their own self-serving or idiosyncratic notions of the public's interest.

The importance of this local value to be used as a reference for the government in making the program considering that society needs leadership from these managers to help it learn what is both desirable and possible to do in public domains for which these managers are temporarily responsible. Nearly always, the politics surrounding a public enterprise are sufficiently contentious to suggest several different plausible and sustainable conceptions of public value (Moore, 1995).

Related with the public value, Smith (2004) suggested the value of the public as a result of social and political interaction. Such interaction involves politicians, officials and communities. Focusing on public value enables one to aggregate issues for scholarly analysis in terms that should also make sense to citizens 
and communities, political activists and people responsible for delivering public services. Focusing on public value can help communities, service providers and political leaders ask and answer a new and wider range of questions while continuing to learn from recent experience, however complex and contested. Therefore the value of the public can provides a path to reconciling democracy and efficiency through dialogue and exchange.

This study finds that formulation of value-based programs in recovery after disaster and social conflict implemented by the provincial government of Nusa Tenggara Timur successfully identifying local values so put it in local development planning. These programs are consistent with the needs and problems encountered by the affected communities and social conflict.

The formulated programs that are relevant to the local value consists of programs that derived from sectors of the economy, human resources, religion, spatial and the environment. Whole the program is related to the communities needs of the affected disaster and social conflict.

The ability of local government financing from local revenue to fund the program that is have not only capable of handling up to a maximum of $26.60 \%$, while the remaining derived from central government transfers.

\section{Literature}

- Anderson, James E., 1978. Public Policy Making. Chicago: Holt, Renehart and Winston.

- Badan Penanggulangan bencana Alam Provinsi NTT, 2008. Laporan Bencana di NTT, Tidak dipublikasikan.

- Creswell, J.W., 1994. Research Design Qualitative and Quantitative Approach. UK-New Delhi-California: Sage-Publication.

- Dunn,William N., 1981, An Introduction to Public Policy Analysis, Englewood Cliff, Prentice-Hall.

- Edward III, George., 1980, Implementing Public Policy, Washinton DC: Congresional Quartely Press.

- Frederickson, H. G., 1997.The Spirit of Public Administration, San Francisco: Jossey-bass Publishers.

- Gismar, Abdul M., Inda Loekman., Lenny Hidayat., Hery Sulistio., Ramot N. Aritonang., Muhammad Chozin., Fitrya Ardziyani Nuril.,2013, Indonesia Governance Index 2012: Tantangan Tata Kelola Pemerintahan di 33 Provinsi, Jakarta: The Partnership for Governance Reform (Kemitraan).

- Jones, C. O., 1984. An Introduction to the Study of Public Policy. Third Edition. California: Wadsworth, Inc. 
- Jun, Jong S., 2006, The Social Construction of Public Administration, Washington: State University of New York Press.

- Kartodihardjo, Hariadi., 2006. Ekonomi dan Institusi Pengelolaan Hutan. Bogor: Institute for Development of Agriculture and Rural Areas (IDEALS)

- Kajian Perdamaian dan Kebijakan., 2013, Peta Kekerasan di Indonesia (Januari-April 2013) dan Kekerasan dalam Pemilukada, Jakarta: The Habibie Center.

- Komisi II DPR-RI, 2010, Laporan Kunjungan Kerja ke-Provinsi NTT. Tidak Dipublikasi.

- Lindblom, Charles E., 1968, The Policy-Making Process, Englewood; Cliffs,NJ: Printice-Hall.

- Michael, Ewen J., 2003,The Foundation of Public Policy, Bundoora: La Trobe University.

- Moore, M., 1994., Public Value as the Focus of Strategy, Australian Journal of Public Administration 53(3): 296-303.

- Moore, M., 1995., Creating Public Value: Strategic Management in Government, Cambridge, Massachusetts: Harvard University Press.

- Nakamura, Robert T,.Frank Smallwood., 1980. The Politics of Policy Implementation, New York: St.Martin's Press.

- Nurjaya, I Nyoman., 1985), Hukum Lingkungan Adat Desa Tenganan Pegringsingan, Tesis, Program Pascasarjana Universitas Gadjah Mada Yogyakarta.

- Nursalam., 2009, Pengaruh Implementasi Kebijakan Tentang Cendana Terhadap Efektivitas Pelestarian Pohon Cendana di Kabupaten Timor Tengah Selatan (TTS) Provinsi Nusa Tenggara Timur (NTT), Disertasi pada Program Pascasarjana Universitas Padjadjaran Bandung.

- Pemerintah Provinsi Nusa Tenggara Timur., Peraturan Daerah Nomor 2 Tahun 2004 Tentang Program Pembangunan Daerah Provinsi NTT.

- Pemerintah Provinsi Nusa Tenggara Timur., 2010, Food Security and Vulnerability Atlas of Nusa Tenggara Timur, Jakarta: Pemerintah Provinsi Nusa Tenggara Timur, Dewan Ketahanan Pangan, Kementerian Pertanian and World Food Programme (WFP).

- Saifullah, A.Djadja,, 2007. Pemikiran Kontenmporer Administrasi Publik, Bandung: LP3An Fisip Unpad.

- Schein, Edgar H., 1985, Organization Culture and Leadership: A Dynamic View, San Fransisco: Jossey Bass.

- Schttschneider, Cf.E.E., 1960., The Semi Sovereign People, New Yor: Holt, Rinehart and Winston.

- Simon, Herbert S., 1957. Administrative Behavior, 2nd Edition, New York, Mac Milan. 
- Simeon, Richard. 1976, Studying Public Policy, Canadian Journal of Political Science, IX No.4.

- Smith, Thomas B. 1973. The Policy Implementation Process. Policy Sciences. Vol 4 No.2.

- Smith, RFI.,2004., Focusing on public value: Something new and something old, Australian Journal of Public Administration 63(4):68-79,

- Sub Direktorat Statistik Ketahanan Wilayah, 2008, Statistik Potensi Desa Provinsi Nusa Tenggara Timur, Jakarta, Badan Pusat Statistik, JakartaIndonesia.

- Tachjan., 2006. Implementasi Kebijakan Publik. AIPI Bandung-Puslit KP2W Lemlit Unpad: Bandung.

- Wahab, Solichin Abdul., 1990. Pengantar Analisis Kebijaksanaan Negara, Jakarta: Rineka Cipta.

- Waldo,Dwight., 1946, Administrative State, San Francisco:Chandler.

- Winarno, Budi., 2002., Kebijakan Publik: Teori, Proses, dan Studi Kasus, Yogyakarta: CAPS Press. 


\title{
Dr Nursalam,
}

Fakultet društvenih i političkih nauka,

Univerzitet „Nusa Cendana“, Kupang, Indonezija

\section{FORMULACIJA PROGRAMA OBNOVE BAZIRANE NA LOKALNIM VREDNOSTIMA (POUKE IZ ISKUSTVA PROVINCIJSKE VLADE ISTOČNA NUSE TENGARA - INDONEZIJA)}

\begin{abstract}
S a ž e t a k
Istraživanjem ćemo pokušati da utvrdimo kako se formuliše socijalna politika nakon elementarnih nepogoda i građanskih sukoba. Korišćena je metoda kvalitativnog istraživačkog dizajna, od skupljanja podataka kroz dokumentaciju i razgovore glavnih činilaca. Oporavak društva od elementarnih nepogoda i građanskih sukoba iziskuje veću umešanost države u formulaciji programa utvrđenih na bazi lokalnih vrednosti. Važnost takvih društvenih projekata leži u tome što daju osnovu u postizanju zajedničkih ciljeva korišćenjem društveno prihvatljivih vrednosti. Formulacija programa obnove bazirane na lokalnim vrednostima u isto vreme su i društveni dizajn, baziran na; 1) zahvalnosti ključnim činiocima; 2) opredeljenje ka rešavanju sukoba, problema i reformama. Prva dimenzija se odnosi na sposobnost rukovodioca da čuje i druga mišljenja, učestvuje u iskustvima drugih i stiče nova znanja. Druga se tiče posvećenosti rukovodioca rešavanju sukoba, problema i promenama, a potezi rukovodioca mogu biti od proaktivnih do reaktivnih. Istraživanje upućuje da je iskustvo lokalne vlade, provincije Istočna Nusa Tengara, u periodu nakon elementarnih nepogoda i sukoba takvo da bi svi iz tog iskustva trebali učiti, jer je uspešno formulisalo plan regionalnog razvoja bazirano na lokalnim vrednostima.
\end{abstract}

Ključne reči: lokalne vrednosti, formulacija politike, društveni dizajn 